\title{
Jaundice after open heart surgery: a prospective study
}

\author{
CHIA-MING CHU, CHAU-HSIUNG CHANG, YUN-FAN LIAW, MING-JANG HSIEH \\ From the Liver Unit and Division of Cardiovascular Surgery, Chang-Gung Memorial Hospital, Lin-Kou \\ Medical Center, Taipei, Taiwan, Republic of China
}

\begin{abstract}
One hundred and fifty four consecutive adult patients having cardiac surgery for a variety of cardiac lesions were evaluated prospectively for postoperative jaundice, those with a raised preoperative serum bilirubin concentration (greater than $34 \mu \mathrm{mol} / \mathrm{l}$ or $2 \mathrm{mg} / 100 \mathrm{ml}$ ) being excluded. The incidence of early postoperative jaundice, as defined by a serum bilirubin concentration of $50 \mu \mathrm{mol} / 1(3.0 \mathrm{mg} / 100 \mathrm{ml})$ or greater, was $23.4 \%$. The jaundice was mild (bilirubin concentration $51-100 \mu \mathrm{mol} / 1(3.0-6.0 \mathrm{mg} / 100 \mathrm{ml}))$ in 26 patients $(16.9 \%)$ and moderate to severe (greater than $100 \mu \mathrm{mol} / \mathrm{l}(6.0 \mathrm{mg} / 100 \mathrm{ml}))$ in 10 patients $(6.5 \%)$. Important contributing factors were the preoperative severity of right heart failure (raised right atrial pressure at heart catheterisation) and hypotension or hypoxaemia and the amount of blood transfused during or shortly after surgery. Age, sex, underlying cardiac lesion, whether halothane was used, operative procedure, duration of cardiopulmonary bypass, and presence or absence of hepatitis B surface antigen were not predictive of postoperative jaundice.
\end{abstract}

It has long been recognised that transient jaundice could appear after a surgical procedure ${ }^{1}$ and that hepatic damage is particularly liable to follow cardiopulmonary bypass. ${ }^{23}$ In one retrospective study early jaundice was seen in $13 \%$ of 232 patients undergoing open heart operations. ${ }^{4}$ In a similar study $8.6 \%$ of 736 patients undergoing open heart surgery developed postoperative jaundice. ${ }^{5}$ There have, however, been only a few prospective inquiries into the incidence and causes of postoperative jaundice. The prospective study of Evans et $a^{6}$ revealed a much higher incidence $(21 \%)$ of postoperative jaundice in patients having major noncardiac operations. The true incidence of early jaundice after open heart surgery is therefore still unclear and awaits further study.

Furthermore, all studies on jaundice after open heart surgery were reported more than 10 years ago, when the medical care of patients undergoing open heart surgery was not as good as today, and when the hepatitis B surface antigen ( $\mathrm{HBsAg}$ ) was not recognised. ${ }^{7} \mathrm{HBsAg}$ carriers are now known to harbour various liver lesions, ${ }^{8}$ which might contribute to the development of postoperative jaundice. ${ }^{9}$ It seemed therefore pertinent to investigate this prob-

\footnotetext{
Address for reprint requests: Dr Yun-Fan Liaw, Liver Unit, Chang-Gung Memorial Hospital, 199 Tung Hwa North Road, Taipei, Taiwan 105, Republic of China.

Accepted 8 September 1983
}

lem further by conducting a prospective study in an area where $\mathrm{HBsAg}$ carriers are common. ${ }^{10}$

\section{Patients and methods}

From August 1979 to November 1980 a consecutive series of 154 adult patients undergoing open heart surgery were entered into this study. For reliable assessment, patients with preoperative jaundice (serum bilirubin concentration $>34 \mu \mathrm{mol} / \mathrm{l}(2 \cdot 0$ $\mathrm{mg} / 100 \mathrm{ml}$ )) were excluded. Seventy-five were male and 79 female, their ages ranging from 16 to 62 years (mean 34 years). The underlying heart lesions are listed in table 1 . None of the patients had a history of hepatobiliary disease.

Concentrations of serum alanine aminotransferase (normal $<40 \mathrm{IU} / \mathrm{l}$ ), alkaline phosphatase (nor$\mathrm{mal}<85 \mathrm{IU} / \mathrm{l}$ ), and bilirubin (normal $<17 \mu \mathrm{mol} / \mathrm{l}$ $(1.0 \mathrm{mg} / 100 \mathrm{ml}))$ were measured by a sequential multiple autoanalyser in all patients. Serum HBsAg was studied by radioimmunoassay (Ausria II-125, Abbott Laboratory, Chicago, Ill) in 144 patients. Cardiac catheterisation had been performed in all and right atrial pressure was measured in 130 patients.

General anaesthesia was induced with halothane in 110 patients and with ether or nitrous oxide in the other 44 patients. All patients had cardiopulmonary bypass, with isovolaemic haemodilution, moderate hypothermia $\left(28^{\circ} \pm 6^{\circ} \mathrm{C}\right)$, and a polystan venothern 
Table 1 Incidence of postoperative jaundice in 154 patients subjected to open heart surgery

\begin{tabular}{|c|c|c|c|c|c|c|}
\hline \multirow[t]{2}{*}{ Heart lesion } & \multirow[t]{2}{*}{$\begin{array}{l}\text { No of } \\
\text { cases }\end{array}$} & \multicolumn{3}{|c|}{$\begin{array}{l}\text { No with maximum total serum bilirubin } \\
(\mu \mathrm{mol} / \mathrm{l}) \text { of }\end{array}$} & \multirow[t]{2}{*}{$\begin{array}{l}\text { Jaundice } \\
\text { No }(\%)\end{array}$} & \\
\hline & & $\leqslant 50$ & $51-100$ & $>100$ & & \\
\hline $\begin{array}{l}\text { Congenital } \\
\text { Mitral valve } \\
\text { Aortic valve } \\
\text { Multiple valve } \\
\text { Coronary heart } \\
\text { Left atrium myxoma }\end{array}$ & $\begin{array}{r}46 \\
72 \\
17 \\
6 \\
11 \\
2\end{array}$ & $\begin{array}{r}36 \\
55 \\
12 \\
3 \\
10 \\
2\end{array}$ & $\begin{array}{r}8 \\
13 \\
3 \\
1 \\
1 \\
0\end{array}$ & $\begin{array}{l}2 \\
4 \\
2 \\
2 \\
0 \\
0\end{array}$ & 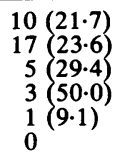 & $41(26 \cdot 3)$ \\
\hline Total & 154 & 118 & 26 & 10 & $36(23.4)$ & \\
\hline
\end{tabular}

Conversion: SI to traditional units-Bilirubin: $1 \mu \mathrm{mol} / \mathrm{l}=0.06 \mathrm{mg} / 100 \mathrm{ml}$.

oxygenator. Seventy four of the operative procedures included valve replacement and 80 did not. Arterial blood gas tensions were measured every 15 minutes during operation and an arterial oxygen tension $\left(\mathrm{PaO}_{2}\right)$ of less than $6.7 \mathrm{kPa}(50 \mathrm{~mm} \mathrm{Hg})$ on at least one occasion was considered to indicate hypoxaemia.

Serum bilirubin, alanine aminotransferase, and alkaline phosphatase were measured on postoperative days $1,2,3,4$, and 7 , or more often if this was indicated clinically. Postoperative jaundice was defined as a serum bilirubin concentration exceeding $50 \mu \mathrm{mol} / \mathrm{l}(3.0 \mathrm{mg} / 100 \mathrm{ml}) .{ }^{4}$ It was classified as mild when the concentration was in the range 51-100 $\mu \mathrm{mol} / \mathrm{l}(3.0-6.0 \mathrm{mg} / 100 \mathrm{ml})$ and moderate to severe when it was greater than $100 \mu \mathrm{mol} / \mathrm{l}$. Arterial blood gas tensions were measured every four hours and systemic blood pressure was monitored every hour during the first three days after operation. Hypoxaemia was defined as $\mathrm{PaO}_{2}$ lower than $6.7 \mathrm{kPa}$ $(50 \mathrm{~mm} \mathrm{Hg}$ ), and hypotension was defined as a blood pressure lower than $90 / 60 \mathrm{~mm} \mathrm{Hg}$ at any time.

The total amount of blood transfused during or just after operation was recorded.

The significance of differences between means was determined by Student's $t$ test. Frequency rates were compared with the $\chi^{2}$ test (with Yates's correction where appropriate).

\section{Results}

JAUNDICE FOLLOWING OPEN HEART SURGERY Jaundice was observed in 36 patients $(23.4 \%)$ mild in $26(16.9 \%)$ and moderate to severe in an additional $10(6 \cdot 5 \%)$. Only three patients had serum bilirubin concentrations greater than $170 \mu \mathrm{mol} / \mathrm{l}$ $(9.9 \mathrm{mg} / 100 \mathrm{ml})$-these were 205,273 , and 616 $\mu \mathrm{mol} / \mathrm{l}(12 \cdot 0,16 \cdot 0$, and $36 \cdot 0 \mathrm{mg} / 100 \mathrm{ml}) \mathrm{respec}-$ tively. The increased serum bilirubin was mainly conjugated (55-79\% of total bilirubin). The incidence of postoperative jaundice was higher in patients with congenital and valvular heart disease than in patients with coronary heart disease, though the difference is not significant (table 1).

Among 36 patients with postoperative jaundice, $31(86.1 \%)$ attained peak serum bilirubin concentrations within three days after operation and these declined rapidly thereafter. The other five patients had peak serum bilirubin levels on postoperative days 4-6 and these then declined gradually. Most patients whose serum bilirubin levels peaked earlier had mild jaundice while those in whom bilirubin levels peaked later tended to have higher levels (table 2).

\section{PREOPERATIVE FEATURES}

Table 3 compares the preoperative features of patients with and without postoperative jaundice. No significant difference was found between these two groups with respect to age, sex, frequency of abnormal serum alanine aminotransferase activity, or $\mathrm{HBsAg}$ positivity. All $20 \mathrm{HBsAg}$ carriers were symptomless, with a mild increase in alanine aminotransferase activity (41-94 IU/l) in seven (35\%) of them. Before operation there were significantly higher frequencies of abnormal right atrial pressure (normal $\leqslant 8 \mathrm{~mm} \mathrm{Hg}$ ) and serum bilirubin concentration $(18-34 \mu \mathrm{mol} / \mathrm{l}(1 \cdot 1-2 \cdot 0 \mathrm{mg} / 100 \mathrm{ml}))$ in patients developing postoperative jaundice.

Table 2 Time of peak serum bilirubin concentration and severity of postoperative jaundice

\begin{tabular}{|c|c|c|c|c|c|c|}
\hline \multirow{2}{*}{$\begin{array}{l}\text { Maximal serum } \\
\text { bilirubin } \\
(\mu \mathrm{mol} / \mathrm{l})\end{array}$} & \multicolumn{6}{|c|}{$\begin{array}{l}\text { Postoperative day of peak serum } \\
\text { bilirubin }\end{array}$} \\
\hline & $l$ & 2 & 3 & 4 & 5 & 6 \\
\hline $\begin{array}{r}51-100 \\
101-170 \\
>170\end{array}$ & $\begin{array}{r}10 \\
2 \\
0\end{array}$ & $\begin{array}{l}7 \\
2 \\
0\end{array}$ & $\begin{array}{l}7 \\
3 \\
0\end{array}$ & $\begin{array}{l}2 \\
0 \\
1 \\
(205)\end{array}$ & $\begin{array}{l}0 \\
0 \\
1 \\
(273)\end{array}$ & $\begin{array}{l}0 \\
0 \\
1 \\
(616)\end{array}$ \\
\hline Total & 12 & 9 & 10 & 3 & 1 & 1 \\
\hline
\end{tabular}

Parentheses indicate serum bilirubin concentrations $(\mu \mathrm{mol} / \mathrm{l})$. Conversion: SI to traditional units-Bilirubin: $1 \mu \mathrm{mol} /=0.06 \mathrm{mg} / 100 \mathrm{ml}$. 
Table 3 Comparison of preoperative features in patients with and without postoperative jaundice

\begin{tabular}{|c|c|c|c|}
\hline & $\begin{array}{l}\text { Without jaundice } \\
(n=118)\end{array}$ & $\begin{array}{l}\text { With jaundice } \\
(n=36)\end{array}$ & $p$ \\
\hline $\begin{array}{l}\text { Age (Mean (SD), years) } \\
\text { Sex (male, No (\%)) } \\
\text { Elevated right atrium pressure }\end{array}$ & $\begin{array}{l}34 \cdot 7(13 \cdot 2) \\
57(48 \cdot 3)\end{array}$ & $\begin{array}{l}31 \cdot 9(11 \cdot 8) \\
18(50 \cdot 0)\end{array}$ & $\begin{array}{l}\text { NS } \\
\text { NS }\end{array}$ \\
\hline (No $(\%)$ ) & $8 / 99(8 \cdot 1)$ & $(10 / 31)(32 \cdot 3)$ & $<0.001$ \\
\hline $\begin{array}{l}\text { Abnormal serum alanine } \\
\text { aminotransferase (No (\%)) } \\
\text { Raised elevated serum }\end{array}$ & $14(11 \cdot 9)$ & $6(16 \cdot 7)$ & NS \\
\hline $\begin{array}{l}\text { Raised elevated serum } \\
\text { bilirubin }(\operatorname{No}(\%)) \\
\text { Serum HBsAg }(\text { No }(\%))\end{array}$ & $\begin{array}{l}8(6 \cdot 8) \\
15 / 109(13 \cdot 8)\end{array}$ & $\begin{array}{l}28(78 \cdot 8) \\
5 / 33(15 \cdot 1)\end{array}$ & $\begin{array}{l}<0.001 \\
\text { NS }\end{array}$ \\
\hline
\end{tabular}

NS-Not significant.

Table 4 Comparison of operative features in patients with and without postoperative jaundice

\begin{tabular}{|c|c|c|c|}
\hline & $\begin{array}{l}\text { Without jaundice } \\
(n=118)\end{array}$ & $\begin{array}{l}\text { With jaundice } \\
(n=36)\end{array}$ & $p$ \\
\hline \multirow{2}{*}{$\begin{array}{l}\text { Halothane anaesthesia (No (\%)) } \\
\text { Cardiopulmonary bypass time (mean } \\
\text { (SD) min) } \\
\text { Hypoxaemia during surgery (No (\%)) }\end{array}$} & $87(73 \cdot 7)$ & $23(63 \cdot 9)$ & NS \\
\hline & $\begin{array}{l}56 \cdot 2(19 \cdot 4) \\
46(39 \cdot 0)\end{array}$ & $\begin{array}{l}50 \cdot 4(17 \cdot 4) \\
21(58 \cdot 3)\end{array}$ & $\begin{array}{l}\text { NS } \\
<0.05\end{array}$ \\
\hline
\end{tabular}

NS-Not significant.

Table 5 Comparison of postoperative features in patients with and without postoperative jaundice

\begin{tabular}{|c|c|c|c|}
\hline & $\begin{array}{l}\text { Without jaundice } \\
(n=118)\end{array}$ & $\begin{array}{l}\text { With jaundice } \\
(n=36)\end{array}$ & $p$ \\
\hline $\begin{array}{l}\text { Hypoxaemia }(\text { No }(\%)) \\
\text { Hypotension (No (\%)) }\end{array}$ & $\begin{array}{l}2(1 \cdot 7) \\
7(5 \cdot 9)\end{array}$ & $\begin{array}{r}6(16 \cdot 7) \\
12(33 \cdot 3)\end{array}$ & $\begin{array}{l}<0.001 \\
<0.001\end{array}$ \\
\hline $\begin{array}{l}\text { Maximum alanine aminotransferase } \\
>200 \text { IU/l }(\text { No }(\%)) \\
>400 \text { IU/l (No }(\%))\end{array}$ & $\begin{array}{l}3(2 \cdot 5) \\
1(0 \cdot 8)\end{array}$ & $\begin{array}{l}9(25 \cdot 0) \\
6(16 \cdot 7)\end{array}$ & $\begin{array}{l}<0.001 \\
<0.001\end{array}$ \\
\hline $\begin{array}{l}\text { Maximum alkaline phosphatase } \\
>85 \text { IU/I (No }(\%) \text { ) } \\
>170 \text { IU/l (No (\%)) } \\
\text { Blood transfused (mean (SD), ml) }\end{array}$ & $\begin{aligned} 37 & (31 \cdot 4) \\
2 & (1 \cdot 7) \\
1436 & (741)\end{aligned}$ & $\begin{array}{r}20(55.6) \\
5(13.9) \\
1953(819)\end{array}$ & $\begin{array}{l}<0.01 \\
<0.02 \\
<0.001\end{array}$ \\
\hline
\end{tabular}

\section{OPERATIVE FEATURES}

The operative features of patients with and without postoperative jaundice are summarised in table 4 . There was no significant difference with respect to the type of anaesthetic or duration of cardiopulmonary bypass, but hypoxaemia during operation was significantly more frequent in patients developing postoperative jaundice.

The incidence of postoperative jaundice was slightly higher in patients who had valve replacement than those who did not, but the difference was not significant $(28.4 \% v 18.8 \%, \mathrm{p}>0.05)$.

\section{POSTOPERATIVE FEATURES}

Table 5 shows the postoperative features of patients with and without postoperative jaundice. Significantly higher frequencies of hypotension and hypoxaemia during the early postoperative period were observed in patients developing jaundice. Moderate to severe increases in serum alanine aminotransferase and alkaline phosphatase activity were observed much more frequently in those developing jaundice. The patients developing jaun-믐 dice had significantly more blood transfused-an average of about $520 \mathrm{ml}$ more. Two patients in the $\dot{0}$ jaundice group died from an intracranial haemo- 3 . rrhage and respiratory failure respectively. The surgical morbidity and mortality rates were no different between jaundiced and non-jaundiced patients.

\section{COMPARISON OF RISK VARIABLES WITH}

REFERENCE TO THE TIME OF PEAK SERUM

BILIRUBIN CONCENTRATION

The above risk variables for postoperative jaundice $N$ were further analysed with reference to the time of peak serum bilirubin concentration. Preoperative ${ }_{\sigma}^{\omega}$ and operative risk variables contributing to the development of jaundice were essentially the same in patients whose serum bilirubin concentration peaked earlier as in those with later peaks. But the latter group had much higher frequencies of hypox-응 aemia and hypotension during the postoperative $\overrightarrow{\mathbb{D}}$ period, had a much larger amount of blood trans- $\overrightarrow{\mathbb{D}}$ fused, and also showed more severe changes in 
serum alkaline phosphatase and alanine aminotransferase at postoperative follow up.

\section{Discussion}

In this prospective study $23.4 \%$ of the patients developed jaundice, mostly of mild degree $(72 \%)$, shortly after open heart surgery. The incidence of jaundice in this series is almost two to three times that found in retrospective studies. ${ }^{45}$ This considerable difference in incidence may be related to the fact that postoperative jaundice of mild degree might be neglected in a retrospective study. On the other hand, the incidence of postoperative jaundice was particularly high (though the difference did not reach significance) in patients with congenital and valvular heart disease, and this trend might contribute to the high overall incidence of jaundice because most of our patients belonged to these two groups (table 1).

This study also shows that many factors may contribute to the development of jaundice after open heart surgery. Before operation the most important contributing factors are high right atrial pressure and hyperbilirubinaemia, both reflecting the degree of liver congestion." Kingsley ${ }^{2}$ and Robinson et $a l^{3}$ have suggested that severe heart failure predisposes the patient to the development of clinical jaundice after cardiopulmonary bypass. Our data also show that among patients whose livers had been congested, as a result either of right heart failure or of tricuspid insufficiency, the incidence of postoperative jaundice was significantly higher. In contrast, this study, unlike previous studies, ${ }^{45}$ failed to show any correlation between the incidence of jaundice and the nature of the cardiac lesions, age, or sex. A poor condition of the liver before operation, as shown by increased serum alanine aminotransferase activity or $\mathrm{HBsAg}$ positivity, also had no influence on the development of clinical jaundice.

Although several investigators have shown a close relationship between halothane anaesthesia and liver dysfunction, ${ }^{12-14}$ our data as well as the findings of other large retrospective and prospective series have failed to show an increased risk of hepatic complication in patients receiving halothane anaesthesia. ${ }^{61^{-17}}$ But this does not rule out the fact that halothane can cause acute liver dysfunction ${ }^{18}$ and most hepatologists, anaesthetists, and surgeons now agree that massive hepatic necrosis is a rare but definite complication of halothane anaesthesia. ${ }^{9}$

During open heart surgery the most important factor that contributed to the development of postoperative jaundice is hypoxaemia, which has long been recognised as an important cause of hepatic damage.${ }^{1920}$ Our data show that the complexity and duration of the open heart operation had no influence on the development of jaundice. This observation also contradicts the findings of retrospective studies. ${ }^{45}$ Furthermore, our data indicate that hypoxaemia and hypotension in the early postoperative period are also important factors contributing to the development of jaundice and tend to delay peaking of serum bilirubin concentrations in these patients. This is understandable because hypotension would reduce hepatic perfusion ${ }^{21}$ and hypoxaemia further decrease hepatic oxygen supply.

Haemolysis of transfused blood is a common factor in postoperative jaundice. ${ }^{622}$ It is particularly important in open heart surgery because both the heart lung machine and the prosthesis shorten the survival of transfused blood. ${ }^{43}$ Though we have not checked the indices of haemolysis, such as serum hepatoglobin and plasma haemoglobin concentrations and red cell survival time, our patients who developed postoperative jaundice had received significantly more transfused blood. This would certainly cause an increased bilirubin load. ${ }^{24}$ In addition, significantly more blood was given to patients whose serum bilirubin reached a peak later in the postoperative period. This might also contribute to the development of more severe jaundice in these patients (table 2).

In summary, this prospective study showed a much higher incidence of jaundice after open heart surgery than has been found in retrospective investigations. It also indicated that the severity of right heart failure before operation and hypoxaemia, hypotension, and amount of blood used during and shortly after operation are factors that contribute significantly to the development of jaundice after open heart surgery. Other factors suggested previously by retrospective studies were not shown to be significant in this study.

We wish to thank Miss SW Hwu for her secretarial assistance.

\section{References}

' Schmid M, Hefti ML, Gasttiker R, Kistler HJ, Senning A. Benign postoperative intrahepatic cholestasis. $N$ Engl J Med 1965;272:545-50.

${ }^{2}$ Kingsley DPE. Hepatic damage following profound hypothermia and extracorporeal circulation in man. Thorax 1966;21:91-8.

${ }^{3}$ Robinson JS, Cole FR, Gibson P, Simpson JA. Jaundice following cardiopulmonary bypass. Thorax 1967; 22:232-7.

${ }^{4}$ Lockey E, McIntyre N, Ross ON, Brookes E, Sturridge MF. Early jaundice after open heart surgery. Thorax 1967;22:165-9 
${ }^{5}$ Sanderson RG, Ellison JH, Benson JA, Starr A. Jaundice following open heart surgery. Ann Surg 1967; 165:217-24.

${ }^{6}$ Evans C, Evans M, Pollock AV. The incidence and causes of postoperative jaundice: a prospective study. Br J Anaesth 1974;46:520-5.

7 Blumberg BS, Alter HJ, Visnich S. A "new" antigen in leukemia sera. JAMA 1965;191:541-6.

${ }^{8}$ Liaw YF, Sung JL. Liver biopsy in asymptomatic carriers of HBsAg. Gastroenterology 1979;76:1084.

${ }^{9}$ Lamont JT, Isselbacher KJ. In: Wright R, Alberti JGMM, Karran SJ, Millward-Sadler GH, eds. Postoperative jaundice in liver and biliary disease. Eastbourne: Sanders, 1979:647-87.

${ }^{10} \mathrm{Wu}$ JS, Chen CH, Chiang YH, Lee YC, Ko YC, Hu HT. Hepatitis $B$ virus infection in Taiwan with reference to anti-HBc versus $\mathrm{HBsAg}$ and anti-HBs. J Formosan Med Assoc 1980;79:760-7.

1 Sherlock S. The liver in heart failure: relation of anatomical, functional and circulatory changes. Br Heart J 1951;13:273-93.

12 Reed WD, Williams R. Halothane hepatitis as seen by the physician. Br J Anaesth 1972;44:935-40.

${ }^{13}$ Klatskin G, Kimberg DV. Recurrent hepatitis attributable to halothane sensitization in an anesthetist. $N$ Engl J Med 1969;280:515-22.

${ }^{14}$ Trowell J, Peto R, Smith AC. Controlled trial of repeated halothane anesthetics in patients with carcinoma of uterine cervix treated with radium. Lancet $1975 ; \mathrm{i}: 821-3$.

${ }^{15}$ Dykes MHM, Chir B, Walzer SG, Slater EM, Gibson
JM, Eliis DS. Acute parenchymatous hepatic disease following general anesthesia. JAMA 1965;193:33944.

${ }^{16}$ Mushin WW, Rosen M, Bowen DJ, Campbell H. Halothane and liver dysfunction: a retrospective study. Br Med J 1964;ii:329-41.

${ }^{17}$ Dodson ME, Richards JG. A prospective study of changes in liver function after operation under two forms of general anesthesia. Br J Anaesth 1972; 44:47-60.

${ }^{18}$ Chen PC, Liaw YF, Chang-Chien CS, Wu CS, Chen L. Hepatitis after halothane exposure. J Formosan Med Assoc 1978;77:685-91.

${ }^{19}$ Popper H. Liver disease: morphologic considerations. Am J Med 1954;16:98-117.

${ }^{20}$ Refsum HE. Arterial hypoxemia, serum activities of GOT, GPT and LDH, and centrilobular liver cell necrosis in pulmonary insufficiency. Clin Sci 1963; 25:369-74.

${ }^{21}$ Mundth ED, Keller AR, Gerald Austen W. Progressive 9 hepatic and renal failure associated with low cardiac output following open heart surgery. $J$ Thorac Cardiovasc Surg 1967;53:275-84.

${ }^{22}$ Kantrowitz PA, Jones WA, Greenberger NJ, Isselbacher KJ. Severe postoperative hyperbilirubinemia simulating obstructive jaundice. $N$ Engl J Med 1967; 276:591-8.

${ }^{23}$ Anderson MN, Gabrieli E, Zizzi JA. Chronic hemolysis : in patients with ball-valve prosthesis. $J$ Thorac Cardiovasc Surg 1965;50:501-10.

${ }^{24}$ Koff RS. Postoperative jaundice. Med Clin North Am 1975;59:823-9. 